\title{
Over de kwaliteit van detentie
}

\author{
Citation for published version (APA):
}

de Jonge, G. (2008). Over de kwaliteit van detentie. Maastricht University Press. https://doi.org/10.26481/spe.20081003gj

Document status and date:

Published: 03/10/2008

DOI:

10.26481/spe.20081003gj

Document Version:

Publisher's PDF, also known as Version of record

\section{Please check the document version of this publication:}

- A submitted manuscript is the version of the article upon submission and before peer-review. There can be important differences between the submitted version and the official published version of record.

People interested in the research are advised to contact the author for the final version of the publication, or visit the DOI to the publisher's website.

- The final author version and the galley proof are versions of the publication after peer review.

- The final published version features the final layout of the paper including the volume, issue and page numbers.

Link to publication

\footnotetext{
General rights rights.

- You may freely distribute the URL identifying the publication in the public portal. please follow below link for the End User Agreement:

www.umlib.nl/taverne-license

Take down policy

If you believe that this document breaches copyright please contact us at:

repository@maastrichtuniversity.nl

providing details and we will investigate your claim.
}

Copyright and moral rights for the publications made accessible in the public portal are retained by the authors and/or other copyright owners and it is a condition of accessing publications that users recognise and abide by the legal requirements associated with these

- Users may download and print one copy of any publication from the public portal for the purpose of private study or research.

- You may not further distribute the material or use it for any profit-making activity or commercial gain

If the publication is distributed under the terms of Article $25 \mathrm{fa}$ of the Dutch Copyright Act, indicated by the "Taverne" license above, 


\section{Over de kwaliteit van detentie}

Het strafvonnis als basis voor detentieplanning 


\section{Colofon}

Ontwerp en print: Océ Business Services, Maastricht

ISBN: 978-90-5681-294-2

NUR: 824

Alle rechten voorbehouden. Niets uit deze uitgave mag worden verveelvoudigd, opgeslagen in een geautomatiseerd gegevensbestand of openbaar gemaakt worden, zonder voorafgaande schriftelijke toestemming van de auteur of uitgever. 


\section{Over de kwaliteit van detentie}

Het strafvonnis als basis voor detentieplanning

\section{IntreeRede}

In verkorte en vrije vorm uitgesproken bij de aanvaarding van het ambt van bijzonder hoogleraar 'detentierecht' aan de Faculteit der Rechtsgeleerheid van de Universiteit Maastricht.

op vrijdag 3 oktober 2008

door

Gerard de Jonge 

Dames en Heren,

Ik neem $U$ even mee op een missie van de Raad van Europa naar Servië, meer bepaald naar de grote gevangenis in de stad Sremska Mitrovica om daar de directie en het personeel kennis te laten maken met de nieuwe Europese gevangenisregels. We krijgen een rondleiding door de inrichting. We kijken naar binnen in een zaal van naar schatting 30 meter lang en 8 meter breed, waarin door de kleine en vuile ramen nauwelijks daglicht doordringt. Er verblijven in het halfduister ongeveer 80 mannen. Haaks op de wanden staan stapelbedden, volgehangen met kleren en vochtige handdoeken. Het is er benauwd en het stinkt. Slecht werkende toiletten en paar gore wastafels bevinden zich helemaal achter in de overbevolkte ruimte. Om daar bij te komen moet voor zwakke gedetineerden elke dag weer een groot probleem zijn. Voorlopig gehechten, kort en lang gestraften, jong en oud zitten 23 uur per dag op die zaal niets te doen. Een dagprogramma is er namelijk niet. Bewaarders wagen zich niet meer dan een paar meter de slaapzaal in en schreeuwen hun bevelen vanuit de deuropening. Besmettelijke ziekten zijn volgens de directie in deze inrichting een groot probleem. Wie nog geen tuberculose had toen hij er binnen kwam heeft het wel als hij er uit komt.

Weer terug in Nederland breng ik met $U$ vervolgens een bezoek aan de gevangenis te Lelystad, waar in een spiksplinternieuwe afdeling het zogenaamde Detentieconcept Lelystad is ontwikkeld. De verblijfsruimten voor de gedetineerden (cellen kunnen dat niet worden genoemd) zijn ruim, goed geventileerd en goed verlicht. In elke ruimte staan, met méters tussen ruimte, drie maal twee stapelbedden opgesteld. Aan het voeteneinde van elk bed is een zogenaamd touch-screen aangebracht. Met behulp daarvan kan een gedetineerde zelf zijn dagprogramma samenstellen: zó laat naar de werkzaal, zó laat naar de recreatie, dan een afspraak met de dokter, vervolgens een bezoek aan de winkel enzovoort. Naast elk beeldscherm hangt een telefoon die men op bepaalde tijdstippen kan gebruiken om naar buiten te bellen. Elke verblijfsruimte beschikt over een afzonderlijke badgelegenheid waar twee man tegelijk gebruik van kunnen maken zonder elkaar in de weg te lopen. Er staan ook een wasmachine en een droogtrommel. De deur van de verblijfsruimte staat overdag open, zodat men op de galerij, waar meer van deze ruimten op uitkomen, met medegedetineerden kan praten Bewaarders zijn op deze afdeling nauwelijks te zien. De bewegingen van gedetineerden én personeel worden op een scherm in een centrale post gevolgd door middel van een elektronisch systeem dat Radio Frequency Identification: 
wordt genoemd. Het personeel beschikt er over palmtopcomputers waarin informatie over alle gedetineerden is opgeslagen. ${ }^{1}$

Een groter verschil als tussen de detentieomstandigheden in Lelystad en die in Sremska Mitrovica is nauwelijks denkbaar.

Wie de kwaliteit van detentie wil afmeten aan het niveau van de materiële detentieomstandigheden zal mede op basis van de rapporten van de Inspectie voor de Sanctietoepassing en de bevindingen van het Straatsburgse Committee for the Prevention of Torture tot de conclusie komen dat die kwaliteit in Nederland relatief hoog is. De kwaliteit van detentie wordt echter niet alleen bepaald door het niveau van de materiele verzorging van gedetineerden maar ook en vooral door de manier waarop zij tijdens hun detentie worden bejegend. Over deze immateriële kant van de detentie wil ik het nu verder hebben, want daar valt naar mijn opvatting nog veel aan te verbeteren. Ik wil de vraag aan de orde stellen hoe aan de gevangenisstraf voor alle betrokkenen - gedetineerden én inrichtingspersoneel - een zinvolle inhoud kan worden gegeven, zinvoller dan thans het geval is. Op dit moment is detentie voor de meeste gedetineerden vooral een kwestie van de tijd doorkomen (doing time, zoals de Amerikanen het uitdrukken). Op het delict waarvoor zij vastzitten worden gedetineerden niet of nauwelijks aangesproken; anders dan men zou mogen verwachten is hun bejegening niet van meet af aan gericht op de aanpak van de problematiek die de oorzaak was van hun detentie. Er wordt (tot nog toe) niet meteen na binnenkomst een detentieplan gemaakt, dat voorziet in een op de problematiek van de gedetineerde toegespitste bejegening, zoals dat bijvoorbeeld wel het geval is in de inrichtingen voor stelselmatige daders en in de justitiële jeugdinrichtingen. In de gevangenissen lijkt het of het delict niet meer bestaat, alsof de inhoud van de detentie los staat van het gepleegde strafbare feit. In gewoon Nederlands: de dader, die kennelijk zó schadelijk wordt geacht, dat hij tijdelijk uit de vrije maatschappij wordt verwijderd, wordt niet meteen bij zijn nekvel gepakt om met hem te gaan werken aan oplossing van de problemen die hij voor de maatschappij en voor zichzelf heeft veroorzaakt. Dat is zonde van de kostbare detentietijd.

Uit een recent onder gedetineerden gehouden rondvraag (een zogenaamde gedetineerdensurvey) blijkt dat zij niet tevreden zijn over de dagbesteding in de inrichting: 'Ze vinden het leven eentonig, vervelen

1 B.Post, S. Stolz en F. Miedema, Evaluatie detentieconcept Lelystad, WODC / ITS, Nijmegen 2007. 
zich in het weekend en zijn van mening dat zij te lang op cel zitten.'2 Ook zij vinden - zij het waarschijnlijk om andere redenen - het verblijf in de gevangenis zonde van de tijd.

Over de tevredenheid van het inrichtingspersoneel is niet veel bekend; dat lijkt vaak al content als er zich tijdens hún dienst geen incidenten voordoen, als het dagprogramma routinematig kan worden afgewerkt en als er 's nachts niemand door het lint gaat. 3 De nadruk in veel detentieregimes ligt op de handhaving van rust en orde, ofwel op 'een ongestoorde tenuitvoerlegging' van straffen en maatregelen. Dat is naar mijn mening een veel te weinig ambitieuze invulling van detentietijd.

\section{Het kan beter}

De gevangenisstraf -en bij voorkeur óók al de voorlopige hechtenis - dient mijns inziens maximaal te worden benut om te werken aan de oplossing van de problematiek, die de gedetineerde met zich meebracht toen hij de inrichting binnen kwam. En die problematiek is meestal zeer complex; het gaat niet alleen om de verdenking van of de veroordeling voor een of meer strafbare feiten, maar ook om de frequent bij gedetineerden voorkomende verslavingen en/of geestelijke stoornissen ${ }^{4}$ en problemen aan het thuisfront. Ik zal de laatste zijn om te beweren dat de Dienst Justitiële Inrichtingen zich niet inspant om haar in vele opzichten problematische clientèle een basale zorg te bieden, maar dat wil nog niet zeggen dat een gevangenisstraf daarmee een zinvolle, effectieve gedragsinterventie is.

Op het terrein van de inhoudelijke bejegening van gedetineerden valt naar mijn overtuiging nog veel aan kwaliteit te winnen. Ik zie daarbij en dat zal hem wellicht verbazen - een belangrijke rol voor strafrechter weggelegd. Op dit moment is de situatie zo, dat met het opleggen van een gevangenisstraf de rechter in feite carte blanche geeft aan de met

2 Ministerie van Justitie, Dienst Justitiële Inrichtingen, Gedetineerd in Nederland 2007 - Een survey onder alle gedetineerden in het Nederlandse gevangeniswezen, Den Haag 2008, bl. 16.

3 Lopend personeelsbelevingsonderzoek zal meer licht gaan werpen over op de vraag hoe het personeel tegenover de inhoud van de bejegening staat.

4 Zie Hierover: C. Schoemaker en G. van Zessen Psychische stoornissen bij gedetineerden - Een verkennend onderzoek in het Penitentiair Complex Scheveningen, Utrecht 1997 en Corinne de Ruiter, Ik heb niets beters te doen (oratie), Maastricht 2007. 
de tenuitvoerlegging van die straf belaste Dienst Justitiële Inrichtingen van het ministerie van Justitie. De veroordeelde wordt, om het zo eens te zeggen, 'zonder bijsluiter' afgeleverd bij de poort van een strafinrichting. Hij verdwijnt dan in een soort black box waaruit hij-tenzij hij levenslang heeft - op een gegeven moment weer te voorschijn komt. Dan is het niet zozeer afwachten óf maar wannéér hij recidiveert. De ongeveer 2 miljard Euro per jaar kostende ${ }^{5}$ Dienst Justitiële Inrichtingen blijkt niet in staat te zijn gedetineerden zodanig te bejegenen dat het merendeel van hen na invrijheidstelling 'delictvrij' blijft. De Dienst Justitiële Inrichtingen meldt op zijn eigen website ${ }^{6}$ dat binnen één jaar na ontslag uit detentie bijna $20 \%$ van de ex-gedetineerden weer wordt ingesloten. Binnen twee jaar na ontslag is $30 \%$ weer gedetineerd geweest en binnen zes jaar na invrijheidstelling heeft bijna de helft weer een keer vast gezeten wegens een strafbaar feit. ${ }^{7}$ De Minister van Justitie deelde de Tweede Kamer onlangs in een brief mee dat - afgaande op de cijfers in voorgaande jaren - ruim 70\% binnen 7 jaar na een verblijf in een penitentiaire inrichting zal recidiveren. ${ }^{8}$ Een duidelijker bewijs van onvermogen kan men zichzelf bijna niet geven. Niettemin wordt op de website van de Dienst Justitielle Inrichtingen de 'missie' van het gevangeniswezen als volgt omschreven:

'De Dienst Justitiële Inrichtingen levert een bijdrage aan de veiligheid van de samenleving door de tenuitvoerlegging van vrijheidsstraffen en vrijheidsbenemende maatregelen en door de aan onze zorg toevertrouwde personen de kans te bieden een maatschappelijk aanvaardbaar bestaan op te bouwen.'

5 Kamerstukken II, $31200 \mathrm{VI}, \mathrm{nr}$. 1, bl.4.

6 www.dji.nl; zoals geraadpleegd op 22 augustus 2008

7 Zie ook: B.S.J. Wartna e.a., Ontwikkelingen in de strafrechtelijke recidive van Nederlandse justitiabelen - Recidivebericht 1997-2004, WODC-recidivestudies Factsheet 2008-2, maart 2008 en B.S.J. Wartna e.a., Strafrechtelijke recidive van ex-gedetineerden Uitstroomperiode 1996-2003 WODC Factsheet 2006-6, september 2006 (via www. wodc.nl - laatstelijk geraadpleegd op 24 augustus 2008)

en B.S.J. Wartna e.a., Recidive 1997 - Een cijfermatig overzicht van de strafrechtelijke recidive van volwassen en jeugdige daders, WODC, reeks Onderzoek en beleid 227, Den Haag 2005.

8 Brief van de Minister en Staatssecretaris van Justitie aan de Voorzitter van de Tweede Kamer van 29 augustus 2008, kenmerk 5549574, onderwerp: over maatregelen recidivereductie: nadruk op nazorg. 
Gezien de - in termen van recidive - teleurstellende resultaten lijkt deze missie vooralsnog een mission impossible. De kwaliteit van de tenuitvoerlegging van straffen en maatregelen is kennelijk onvoldoende om deze aan zichzelf gegeven opdracht waar te maken.

Het gevangeniswezen pleegt kritiek op zijn tekortkomingen te pareren door regelmatig bij monde van de verantwoordelijke minister of staatssecretaris hervormingen aan te kondigen, zoals enkele weken geleden weer eens het geval was. Deze dienst wekt daarmee telkens de suggestie dat de gesignaleerde problemen verholpen zullen worden. Leveren de plannen vervolgens niet het beoogde resultaat op, bijvoorbeeld omdat de gedetineerdenpopulatie moeilijker te beheren is dan gedacht of omdat er te weinig draagvlak voor de plannen onder het personeel bestaat, dan worden de plannen bijgesteld of vervangen door een compleet nieuwe aanpak. Het gevangeniswezen weet dat het nooit failliet zal gaan, dat het van regering en parlement altijd weer een doorstart mag maken omdat het - hoe gering zijn bijdrage tot vergroting van de veiligheidsgevoelens ook moge zijn - door bijna iedereen als een onmisbaar onderdeel van de rechtshandhaving wordt gezien.

Ook al slaagt het gevangeniswezen er niet in zijn opdracht te vervullen, het is mijns inziens niet redelijk om alleen deze schakel van de zogenaamde strafrechtsketen daar verantwoordelijk voor te houden. Als deze justitiële dienst onvoldoende kwaliteit levert is dat zeker niet alleen te wijten aan het management van deze institutie. Het gevangeniswezen kan een groot deel van de verantwoordelijkheid voor zijn functioneren neerleggen bij de instanties die de strafinrichtingen van hun bevolking voorzien. Dat zijn het openbaar ministerie en de strafrechter. Het ligt mijns inziens op de weg van deze 'toeleveranciers' om in strafeis en in vonnis zo nauwkeurig mogelijk aan te geven wat er in het kader van de tenuitvoerlegging van een gevangenisstraf aan een veroordeelde moet worden 'vertimmerd'. De officier van justitie acht het echter niet zijn taak om daar in zijn requisitoir aandacht aan te besteden en de strafrechter geeft in zijn uitspraak zelden een indicatie wat de Dienst Justitiële Inrichtingen met een tot gevangenisstraf veroordeelde moet aanvangen. De inhoud van een gevangenisstraf doet er voor hen kennelijk weinig toe. Dat geldt in mindere mate voor veroordelingen tot een maatregel als plaatsing in een inrichting voor stelselmatige daders, terbeschikkingstelling of plaatsing in een inrichting voor jeugdigen. Uit de in die zaken - verplicht uitgebrachte - gedragskundige rapportage, waarnaar de rechter in zijn uitspraak pleegt te verwijzen, valt voor de inrichting waar de veroordeelde terecht komt meestal wel op te 
maken aan welke problematiek gedurende de vrijheidsbeneming dient te worden gewerkt, ook al zijn de gedragskundige rapporten naar mijn inschatting over het algemeen sterker wat betreft de diagnose van de problemen dan wat betreft adviezen over de meest effectieve behandeling daarvan.

Bij veroordeling tot een gevangenisstraf wordt door de rechter volstrekt in het midden gelaten wat de bejegening van de veroordeelde moet inhouden en wordt de concrete invulling daarvan geheel aan het gevangeniswezen overgelaten. In vonnissen oude stijl wordt volstaan met een standaardmotivering. In de moderne PROMIS-uitspraken (ik kom op de betekenis van deze term nog terug) wordt een aantal strafverhogende of verlagende omstandigheden genoemd, maar ook deze bevatten geen aanwijzingen betreffende de tenuitvoerlegging van de straf. De wet eist ook helemaal niet dat een rechter zulke aanwijzingen geeft. De strafrechter zou zulke aanwijzingen trouwens ook moeilijk kúnnen geven omdat hij vaak niet op de hoogte is van wat er in het kader van de tenuitvoerlegging van een gevangenisstraf aan gedragsbeïnvloeding mogelijk is. Strafrechter en gevangeniswezen zijn elkaar tamelijk vreemd; de strafrechtsketen is op dat punt onderbroken.

Naar mijn mening dient in deze situatie verandering te komen. De inhoud en strekking van strafeis, straftoemeting en strafuitvoering dienen - wat ik zou willen noemen - in plaats van vergeldend, probleemgeoriënteerd en zo mogelijk herstelgericht te worden, gericht te zijn op de oplossing van de problemen die de veroordeelde voor derden en voor zichzelf heeft veroorzaakt. Alleen door zo'n probleemgeoriënteerde straftoemeting en een daarop gebaseerde, eveneens probleemgeoriënteerde tenuitvoerlegging kan een gevangenisstraf méér zijn dan het tijdelijk uitschakelen en onzichtbaar maken van een tot delinquent bestempelde medeburger. Ik sluit me graag aan bij de opvatting van de forensisch psychologe Corinne de Ruiter, die een klassiek strafdoel als vergelding zinloos noemt omdat het is gebaseerd op het concept van vrije wil en individuele verantwoordelijkheid, welk concept volgens haar in strijd is met de resultaten van fundamenteel psychologisch onderzoek. Daaraan voeg ik toe dat vergelding als grond of doel van een straf ook al zinloos is omdat dit moeilijk te omlijnen begrip door iedereen anders wordt uitgelegd. De klassieke strafrechtfilosoof zal volhouden dat vergelding toevoeging van verdiend leed is en tevens de grond en grens van het recht tot straffen is. ${ }^{9}$ De psycholoog vraagt zich af of een vergeldende straf als gekanaliseerde particuliere wraakzucht een emotionele 
behoefte bevredigt of niet zozeer een psychologisch, dan wel een sociaal fenomeen met een politieke of juridische motivering is. ${ }^{10}$

De strafrechter pleegt de maat der vergelding, voorzover die element is van een door hem op te leggen straf, te relateren aan 'de ernst van het feit', alsof daarmee een objectieve maatstaf kan worden verkregen over de toepasselijke strafsoort-, maat en modaliteit. Dat is niet zo en daarom is straftoemeting die mede of vooral op vergelding berust in hoge mate willekeurig." Om met Groenhuijsen te spreken: het concept van vergelding biedt geen maatstaf om in een concreet geval een aannemelijke straf te vinden. ${ }^{12}$

Handhavingvan hetvage,metafysischevergeldingsconcept belemmert mijns inziens een rationele, probleemgeoriënteerde straftoemeting en dito strafuitvoering. Om de weg daartoe vrij te maken lijkt het zinvol om de suggestie van De Hullu op te volgen om het dogmatische onderscheid tussen straf en maatregel op te heffen en het sanctiebegrip te vervangen door de volgende geobjectiveerde omschrijving:'een in een strafrechtelijk kader uitgesproken overheidsreactie op overtreding van een strafbepaling $(. . .)^{13}$.

Een strafrechter, die bereid is verder te denken dan in termen van vergelding, dient in mijn visie, als hij het opleggen van een gevangenisstraf onvermijdelijk acht, in zijn uitspraak instructies te geven aan het gevangeniswezen betreffende de inhoudelijke bejegening van de veroordeelde. Diezelfde strafrechter dient daarnaast een zekere verantwoordelijk te krijgen voor de tenuitvoerlegging van de door hem bevolen vrijheidsbeneming. Hij dient periodiek te toetsen of hetgeen hij met de oplegging van een gevangenisstraf heeft beoogd, tijdens de

9 L. Polak, De zin der vergelding - Een strafrechts-filosofies onderzoek, Deel I, Amsterdam 1921, p. XX.

10 N. Frijda, De lex talionis: over wraak, in diens bundel De psychologie heeft zin, Amsterdam 1993, bl. 159-196.

11 G. de Jonge, In de klem van de vergelding, in P.L. Bal e.a., Veiligheid of vergelding? Deventer 2003, bl. 162-163.

12 M.S. Groenhuijsen, Schuld en Boete - Een Beschouwing over de strafrechtelijke verantwoordelijkheid, in: M.A.P. Bovens e.a., Verantwoordelijkheid en realtiteit verantwoordelijk in publiek recht, politiek en maatschappij, Zwolle 1989, bl. 56

13 J. de Hullu, Enkele suggesties voor herziening van het strafrechtelijk sanctiestelsel, in: Handelingen Nederlandse Juristen-Vereniging, 132e jaargang/ 2002-1, Deventer 2002, bl. 9 en 62 . 
tenuitvoerlegging daarvan ook wordt gerealiseerd. Daarmee pleit ik niet voor de invoering van het in de literatuur wel besproken model van strafuitvoerings- of executierechter (een onaangename term die mij te veel aan een scherprechter doet denken) maar wel voor het creëren van de mogelijkheid de tenuitvoerlegging van die straf te volgen en zonodig bij te sturen, zoals dat bijvoorbeeld ook bij de ISD maatregel mogelijk is. Een zekere betrokkenheid bij de tenuitvoerlegging van de door hem opgelegde straf heeft tot gevolg dat de strafrechter op de hoogte blijft van de effecten van zijn beslissing, een terugkoppeling die op dit moment ontbreekt. De straftoemeting én de tenuitvoerlegging van een straf kunnen daarmee aan kwaliteit winnen.

Voordat ik nader inga op de manier waarop de strafmotivering richtinggevend zou kunnen worden voor de uitvoering van de gevangenisstraf zal ik nu eerst een korte schets geven van de belangrijkste hervormingen van het Nederlandse gevangeniswezen om daarmee duidelijk te maken dat deze hervormingen tot nu toe niet hebben geleid tot de door mij voorgestane probleemgeoriënteerde, effectieve tenuitvoerlegging van de gevangenisstraf.

\section{Het gevangeniswezen als perpetuum mobile}

Het ingrijpende, ultieme karakter van de vrijheidsstraf heeft het gevangeniswezen van meet af aan met een legitimatieprobleem opgezadeld: hoe kan het opsluiten van mensen en vooral de manier waarop dat gebeurt, worden gerechtvaardigd? Het geweten van democratische justitiële autoriteiten, politici en academici heeft op dit punt altijd geknaagd. Vandaar de niet aflatende pogingen het gevangeniswezen te hervormen.

In zijn fameuze boek Surveiller et Punir heeft Foucault laten zien hoe onverbrekelijk pogingen om het gevangeniswezen te hervormen met dit instituut zijn verbonden en hoe weinig resultaat die pogingen zijns inziens hebben opgeleverd. Hervormingspogingen zijn in zijn visie altijd tot mislukken gedoemd omdat het voortbestaan van de gevangenis in het belang zou zijn van de machthebbers van het moment. Deze zouden baat hebben bij het in stand houden van de door dit instituut gecreëerde figuur van 'de delinquent', omdat die de aandacht afleidt van illegaal gedrag van die machthebbers zelf.14 De Nederlandse abolitionisten

14 M. Foucault, Surveiller et punir - Naissance de la prison, Parijs 1975, bl. 236-238. 
van weleer (wie kent ze nog?) plachten regelmatig Foucault te citeren wanneer zij betoogden dat de gevangenis intrinsiek slecht is en eenvoudig niet te hervormen valt. Alleen 'negatieve hervormingen' konden in hun ogen genade vinden. Daarmee bedoelden zij hervormingen, die kunnen bijdragen tot afschaffing van het gevangeniswezen als instituut. Ik deel Foucault's cynische analyse niet, althans niet helemaal, en meen dat het gevangeniswezen, en ik spreek nu over het Nederlandse, wel degelijk in positieve zin te veranderen valt, met name wat betreft de inhoud van de bejegening.

\section{Van Koning Willem I tot Staatssecretaris Albayrak}

Koning Willem I heeft aan het begin van de 19e eeuw de verwaarloosde, van de Republiek geërfde rasp- tucht en werkhuizen gesaneerd en gecentraliseerd. Dit resulteerde in de vaststelling van een aantal minimumnormen betreffende de huisvesting en materiele verzorging van gevangenen, neergelegd in het Besluit houdende Organisatie der Gevangenissen van 1821. Deze eerste grote hervorming van dit uit de 16 e eeuw stammende instituut ${ }^{15}$ betrof vooral de materiële detentieomstandigheden van gedetineerden. ${ }^{16}$ Over de inhoudelijke bejegening van gedetineerden was dit besluit kort: zij moesten goederen voor 's Rijks dienst produceren en kerkgang was verplicht. Kort na deze grote reorganisatie volgde een heftig debat op academisch, ambtelijk en politiek niveau over de vraag welk regiem het meest geschikt was om de gevangenen zedelijk te verbeteren. Deze discussie is samen te vatten onder de noemer 'cel of gemeenschap'. Dit leidde medio 19e eeuw tot de invoering van een strenge variant van het, uit de Verenigde Staten overgewaaide, cellulaire stelsel waarvan de verwoestende gevolgen op lichaam en ziel van de gevangenen door Herman Franke gedetailleerd zijn beschreven. ${ }^{17}$ Deze zeer ingrijpende 'hervorming' werd formeel pas na de Tweede Wereldoorlog, met de invoering in 1953 van de

15 Opsluiting in tucht- werkhuizen was destijds wat wij nu een alternatieve straf zouden noemen; deze werd namelijk een alternatief voor - daarnaast overigens gehandhaafde verbanning, de lijf- en de doodstraf. Daarover: Pieter Spierenburg, The Prison Experience - Disciplinary Institutions and Their Inmates in Early Modern Europe, New Brunswick and London, 1991, hoofdstuk 3.

G. de Jonge, Strafwerk - Over de arbeidsverhouding tussen gedetineerden en Justitie, Breda 1994, bl. 24-26.

17 H. Franke, Twee eeuwen gevangen - misdaad en straf in Nederland, Utrecht 1990, 
Beginselenwet gevangeniswezen ongedaan gemaakt. Mede op basis van de ervaringen van verzetsstrijders die tijdens de bezetting aan den lijve hadden ervaren wat eenzame opsluiting met lichaam en geest doet, konden gevangenen voortaan aan gemeenschappelijk activiteit deelnemen 'onder krachtige, deskundige en inspirerende leiding', zoals de Commissie Fick, het in haar rapport verwoordde. ${ }^{18}$ De door de commissie voorgestelde bepalingen betreffende het gevangenisregime hielden geen verband met enig strafdoel omdat de commissie Fick bij de voorbereiding van de nieuwe wet een vruchteloos debat daarover wilde vermijden. Wel diende volgens Fick en de zijnen de tenuitvoerlegging van straffen en maatregelen mede te zijn gericht op de reclassering van veroordeelden. Deze opdracht werd neergelegd in het dubbelzinnige artikel 26 van de genoemde Beginselenwet gevangeniswezen, dat luidde:

'Met handhaving van het karakter van de straf of de maatregel wordt hun tenuitvoerlegging mede dienstbaar gemaakt aan de voorbereiding van de terugkeer der gedetineerden in het maatschappelijk leven.'

Wat precies onder 'het karakter van de straf of maatregel' diende te worden verstaan werd in het midden gelaten, maar er is weinig fantasie voor nodig om te begrijpen dat daarmee een vergeldend, leedtoevoegend element van de tenuitvoerlegging werd bedoeld. Verder blijkt uit de zinsnede 'de terugkeer der gedetineerden in het maatschappelijk leven' dat wat er binnen de muren van penitentiaire inrichtingen gebeurde destijds niet werd beschouwd als onderdeel van het maatschappelijk leven. Gedetineerden waren buiten de maatschappij geplaatst. Het gevangeniswezen was in de kern een autonoom opererende, door eigen formele en informele wetten geregeerde, naar binnen gekeerde organisatie, van waaruit gedetineerden bij hun invrijheidstelling als na een verblijf op de maan de aarde weer betraden.

Ook bij daarop volgende hervormingen of hervormingspogingen van het gevangeniswezen werd er niet aan gedacht een duidelijke verbinding te leggen tussen de aard van de bejegening van gevangenen en de

18 Rapport van de commissie voor de verdere uitbouw van het gevangeniswezen (commisieFick), 's-Gravenhage 1947.

19 G. de Jonge, De koers van het Nederlandse gevangeniswezen sinds de Tweede Wereldoorlog, Justitiële verkenningen, 4 2007, bl. 31-43. 
grondslag en het doel van de vrijheidsstraf. ${ }^{19}$ De vrijheidsbeneming bleef in naam wel mede in het teken staan van de reclassering van veroordeelden en er kwamen executiemodaliteiten bij, zoals half open en open inrichtingen. Een beperkt aantal gedetineerden werd met behulp van de zogenoemde 'binnenreclassering' zo goed en zo kwaad als het ging voorbereid op hun invrijheidstelling. Het gevangeniswezen kreeg daardoor iets meer aansluiting met de 'vrije' maatschappij.

In zijn in 1964 gepresenteerde beleidsnota Het Nederlandse gevangeniswezen bepleitte minister Scholten - en dat was toen toch een nieuw inzicht - een gecoördineerd optreden in de judiciële, de penitentiaire en de post-penitentiaire fase. Daarnaast onderstreepte hij de noodzaak de rechtspositie van gedetineerden te verbeteren. Van de voorgestelde ketenbenadering avant la lettre kwam uiteindelijk niet veel terecht, maar de rechtspositie van gedetineerden werd wél verbeterd: in 1977 kregen gedetineerden de bevoegdheid te klagen over beslissingen van de directeur. Zo werden zij eindelijk als rechtssubject erkend. Deze juridische emancipatie van gedetineerden kan worden beschouwd als misschien wel de belangrijkste hervorming op penitentiair gebied sinds de opening van het Amsterdamse Rasphuis in 1596. Gedetineerden kunnen zich sinds de invoering van het beklagrecht verweren tegen inbreuken op hun rechten en tegen een willekeurige behandeling. Deze juridische emancipatie ging echter niet zó ver dat gedetineerden invloed kregen op de inhoud van hun bejegening: De feitelijke invulling van de regimes en de daarbij behorende dagprogramma's bleef voorbehouden aan de directies van de penitentiaire inrichtingen.

Vanaf het einde van de 70-er jaren, als het reïntegratie-ideaal zijn glans aan het verliezen is, wordt de inhoud van de beleidsnota's betreffende de hervorming van het gevangeniswezen steeds meer bepaald door de noodzaak tot bezuinigen. Het reclasseringsideaal wordt verruild voor managementsdenken. Ook de reclassering zelf verzakelijkt en dat moet zij wel om haar subsidie niet te verliezen. Het hoogste doel van de verantwoordelijke bewindslieden lijkt dan nog te liggen in de 'beperking van detentieschade', waarmee met zoveel woorden wordt erkend dat detentie in beginsel schadelijk is. Het destijds gestaag toenemend aantal gedetineerden diende zo efficiënt mogelijk te worden gehuisvest. Het accent kwam te liggen op wat de Amerikanen noemen: warehousing. Het door minister Korthals Altes in zijn nota Samenleving en criminaliteit omhelsde 'veiligheidsdenken' domineert sinds 1985 alle aan de hervorming van het gevangeniswezen gewijde beleidsnota's, zoals het rapport van de 
Evaluatiecommissie beveiligingsbeleid van 1992 en de ambitieuze nota Werkzame detentie van 1994, waarin werd gesteld dat gedetineerden vooral door het verrichten van winstgevende arbeid weer op het goede pad zouden kunnen worden gebracht. De obsessie met veiligheid vond zijn bekroning in de Penitentiaire beginselenwet van 1999, die de penitentiaire inrichtingen indeelt naar de mate van hun beveiliging. Gedetineerden worden voortaan primair geselecteerd en geplaatst op basis van hun risicoprofiel. We kennen sinds kort zelfs speciale terroristenafdelingen

De vraag met welk doel vrijheidsstraffen worden opgelegd speelde ook bij de totstandkoming van de Penitentiaire beginselenwetwet nauwelijks een rol. Het gaat sindsdien in de beleidsstukken vooral om de aanpak van logistieke en financiële problemen, culminerend in samenplaatsing van gedetineerden en een systematische bekorting van de dagprogramma's. De inhoudelijke bejegening van de clientèle werd steeds meer bijzaak. De regimes werden tot op het bot 'versoberd'. De reclassering verdween uit de inrichtingen op een moment waarop de eigen staf geen ruimte had om maatschappelijke zorg te verlenen, een taak die noodgedwongen deels door de geestelijke verzorging werd overgenomen.

De laatste jaren schuiven als hervormingsprogramma's vermomde bezuinigingsoperaties als kruiend ijs over elkaar, te beginnen met het beleidsdocument De Nieuwe Inrichting, dat alleen een kleine groep gemotiveerde gedetineerden een zinvolle invulling van de straftijd beloofde. Deze nota werd al snel ingehaald door het - nooit volledig geïmplementeerde - plan Detentie en behandeling op maat (DBM), dat op zijn beurt weer werd overlopen door het project Modernisering gevangeniswezen. Dat laatste plan werd dermate wantrouwend door het veranderingsmoede en voortdurend ingekrompen personeel ontvangen dat de uitvoering ervan op zijn minst problematisch is geworden. Illustratief is hier wat de belangenbehartiger van het gevangenispersoneel van de ABVAKABO FNV daarover heeft gezegd: (ik citeer): "Eerst moet er bepaald worden welke dagprogramma's en activiteiten ervoor zorgen dat gevangenen beter uit de gevangenis komen. Hiermee vergroot je de kans dat zij niet voor een tweede keer de fout in gaan en daarmee dat de samenleving er veiliger op wordt. Dan kan gekeken worden naar de hoeveelheid en bekwaamheid van het personeel en in welk soort gevangenissen zij zullen werken. Nu wordt er bezuinigd op de normprijzen, waardoor de dagprogramma's onmenselijk voor de

20 Jan Willem Dieten, in een op 4 juli 2008 op de website (www.abvakabofnv.nl) van deze bond gepubliceerd bericht. 
gevangenen worden en onwerkbaar voor het personeel. De veiligheid in de gevangenissen en de samenleving is daarmee niet gediend."20

\section{Het recidivespook}

Hoe is de situatie op dit moment? Minister Hirsch Ballin en zijn Staatssecretaris Albayrak hebben eind augustus alweer nieuwe beleidsplannen gepresenteerd. Deze komen - kort gezegd - hier op neer, dat nog deze kabinetsperiode de recidive van volwassen ex-gedetineerden met $10 \%$ moet dalen. ${ }^{21}$ Deze doelstelling moet worden bereikt door middel van een - wat de bewindslieden noemen - een persoonsgerichte aanpak, neergelegd in een persoonsgericht detentieplan, door het dagprogramma volledig in te richten op de stimulering van de eigen verantwoordelijkheid van de gedetineerden en hun naast standaardactiviteiten een zo toegespitst mogelijk dagprogramma aan te bieden. In dit nieuwe plan ligt de nadruk op het organiseren van een goede nazorg. Daarbij wordt aan de gemeenten waar ex-gedetineerden gaan wonen een belangrijke ondersteunende taak toebedacht. Verder dient er dient er volgens dit jongste plan ten behoeve van de zorg voor geestelijk gestoorde gedetineerden een betere aansluiting te komen tussen de forensische zorg en de reguliere geestelijke gezondheidszorg.

Dit overzicht van de sinds het beging van de 19e eeuw uitgevoerde of geplande hervormingen laat zien dat het gevangeniswezen een zeer onrustige organisatie is, die telkens met nieuw beleid wordt geconfronteerd terwijl oude plannen nog niet tot het einde zijn doorgevoerd of behoorlijk zijn geëvalueerd. Het gevangeniswezen probeert onophoudelijk, maar zonder erg veel succes, zichzelf opnieuw uit te vinden.

In de jongste plannen gaat tot verrassing van velen het roer weer helemaal om en gaat het - net als in de 6o- er en 70-er jaren van de vorige eeuw weer helemaal om de persoon van de dader. Daar ben ik persoonlijk wel gelukkig mee, maar ik vraag me af of het systematisch verschraalde gevangeniswezen deze omslag zal kunnen realiseren. De heersende managementbenadering is niet zo maar te vervangen door een welzijns- dan wel zorgbenadering. Daarbij bestaat het gevaar dat een

21 Of dit plan slaagt kan echter pas geruime tijd na deze kabinetsperiode worden vastgesteld. Zie de in noot 8 genoemde brief, bl.13. 
volgend kabinet weer totaal anders over de aanpak van gedetineerden kan denken, en het roer alweer om zal gaan, zeker wanneer populistische partijen deel van zo'n kabinet zouden uitmaken.

De kwaliteit van de bejegening van gedetineerden mag mijns inziens niet afhangen van de min of meer toevallige signatuur van een kabinet, maar dient rechtstreeks verband te houden met de bedoeling van degene die een straf toemeet: dat is de strafrechter. Zijn beslissing dient in mijn visie bepalend te zijn voor de inhoud van de tenuitvoerlegging van de vrijheidsstraf en hij dient er voor te waken dat zijn beslissing ook wordt uitgevoerd zoals hij heeft bedoeld. Het persoonlijke detentieplan, dat als het aan de minister van justitie en diens staatssecretaris ligt binnenkort voor iedere gedetineerde wordt opgemaakt, dient de bedoeling van de straf te reflecteren. Dat is echter moeilijk te realiseren zolang straftoemetingsbeslissingen in dit opzicht niet goed worden gemotiveerd, ondanks recente inspanningen daar verbetering in te brengen. Zolang de directeur van een penitentiaire inrichting niet weet waarom en met welk doel een bepaalde gevangenisstraf is opgelegd zal hij zelf de inhoud van een detentieplan bepalen en is de bejegening van gedetineerden totaal afhankelijk van de toevallige inzichten van degenen die een detentieplanning maken.

Voordat ik met $U$ het probleem van de strafmotivering zal bespreken lijkt het mij nuttig om de rol van het openbaar ministerie bij de straftoemeting te belichten, want hoewel de strafeis niet maatgevend voor de uitspraak hoeft te zijn, zal deze in het algemeen het startpunt van de beraadslaging over de op te leggen straf of maatregel zijn.

\section{De strafeis van het openbaar ministerie mag geen verrassing zijn}

In het debat over straftoemeting wordt regelmatig gesproken over de verhouding tussen strafvorderingsrichtlijnen en rechterlijke oriëntatiepunten, maar een belangrijke vraag wordt daarbij niet gesteld, namelijk de vraag hoe het zit met de motivering van de strafeis. Waar artikel 359 Sv nog zekere eisen aan de strafrechter stelt wat betreft de motivering van de opgelegde straf of maatregel, worden dergelijke eisen merkwaardigerwijs niet aan het requisitoir van de officier van justitie gesteld. Artikel $311 \mathrm{~Sv}$ - het enige artikel dat over dat requisitoir gaat - zegt niet meer dan dat nadat de ondervraging van de verdachte 
heeft plaatsgehad en de aanwezige getuigen en deskundigen zijn gehoord, de officier van justitie het woord kan voeren. En dan gaat het verder: 'hij legt zijn vordering na voorlezing aan de rechtbank over. De vordering omschrijft de straf en maatregel, indien oplegging daarvan wordt geëist;' dat is alles. De wet verplicht de officier niet zijn eis te onderbouwen. Het is op een zitting vaak tot het laatste moment voor alle aanwezigen een verrassing wat de eis zal zijn. Nu zal de strafeis in de wat kleinere, veel voorkomende zaken meestal niet veel van de toepasselijke strafvorderingsrichtlijn (zo voorhanden) afwijken, maar in de wat zwaardere zaken wordt de eis niet zelden als het bekende konijn uit de hoge hoed van de officier getoverd, waardoor een goed debat over de meest adequate sanctiesoort, -maat en -modaliteit niet mogelijk is. In feite wordt door deze verrassingspraktijk een verdedigingsbelang geschaad omdat verdachte en diens raadsman zich niet goed op de strafeis hebben kunnen voorbereiden.

Het lijkt mij niet alleen wenselijk maar zelfs noodzakelijk, dat waar van de strafrechter een steeds betere motivering van zijn straftoemeting wordt verlangd, ook van de officier wordt gevergd dat deze zijn strafeis goed onderbouwt. Een tweede eis die wat mij betreft aan het openbaar ministerie gesteld kan worden is, dat het de voorgenomen strafeis al vóór de zitting aan de verdachte en diens raadsman ter kennis brengt, gelijktijdig met of zelfs als onderdeel van de dagvaarding. Artikel 261 Sv zou met dat doel dienen te worden aangevuld. Verdachten dienen in staat te worden gesteld zich gedegen voor te bereiden op de héle zitting, dus ook op de te verwachten strafeis. Ook dat hoort naar mijn mening bij het recht op een eerlijk proces in termen van artikel 6 van het EVRM. De tevoren bekend gemaakte concept-eis kan vervolgens naar aanleiding van wat er op de zitting is gezegd en gebleken door de officier of advocaat-generaal worden bijgesteld. In zijn requisitoir dient de officier zijn definitieve eis dan uitdrukkelijk te onderbouwen om zo de rechter een duidelijk uitgangspunt te bieden voor de beraadslaging over de straf of maatregelen die uiteindelijk wordt opgelegd.

\section{De straftoemeting: rijp voor een kwaliteitssprong}

Ik ga met $U$ terug in de tijd en wel naar 1888. In dat jaar, in de tweede jaargang van het mede door hem opgerichte Tijdschrift voor Strafrecht, 
citeert de Groningse hoogleraar straf- en strafprocesrecht Jacob Domela Nieuwenhuis ${ }^{22}$ de volgende opmerking van een zekere Dr. J. Füssling, destijds directeur van een cellulaire gevangenis te Bruchsal in Baden. Deze had tijdens een lezing gezegd: 'Het is (...) een hoofdfout, dat (...) de rechtsgeleerden in den regel slechts daarin behagen en belang schenen te stellen om rechtsvragen te ventileeren en kunstige vonnissen te scheppen, maar er zich niet om bekommerden, hoe hunne wijsheid zich in het leven vertoont en welke werkelijke gevolgen de rechtsuitspraken hebben. Als zulke rechters (...) eenmaal de gronden van schuld en onschuld afgewogen en in een verhouding, die als proefstuk van scherpzinnigheid dienen kan, analytisch hadden te samengesteld, geloofden zij voor God, den koning en hun geweten genoeg gedaan te hebben. Zij gingen tot anderen arbeid over, zonder zich af te vragen wat er van de zaak verder zou worden. Met de uitvoering, de inrichting der straf, met zulke allotriën ${ }^{23}$ konden zij zich niet bemoeien.' ${ }^{24}$

Dr. Füssling mag dan in de vergetelheid zijn geraakt, diens constatering is nog steeds geldig: de strafrechter handelt gewetensvol de strafvorderlijke voor- en hoofdvragen af. Daarmee acht hij zijn werk te zijn gedaan. Hoe er met de gestrafte of 'gemaatregelde' tijdens diens detentie wordt omgesprongen is niet zijn bekommernis. Van een ketenbenadering een door Justitie te pas en te onpas gebruikte term - is hier allerminst sprake: er is geen structureel verband tussen wat de strafrechter doet en het functioneren van de Dienst Justitiële Inrichtingen.

De strafrechter geeft in zijn uitspraak niet aan wat er zijn inziens met de veroordeelde tijdens diens detentie moet gebeuren. Hij hoort ook nooit iets terug over de gevolgen van de door hem gelaste vrijheidsbeneming voor veroordeelde en maatschappij. De dienst justitiële inrichtingen koppelt de resultaten van de bejegening van de veroordeelden niet terug naar de strafrechter. Straftoemeting en strafuitvoering zijn niet op elkaar afgestemd. Straftoemeting is éénrichtingsverkeer. De bestraffers weten meestal niet - en willen vaak ook niet weten - wat zij een veroordeelde aandoen.

Ik zal nu proberen uit te leggen hoe daar door een gerichte, rationele straftoemeting verandering in kan - en wat mij betreft zou moeten -

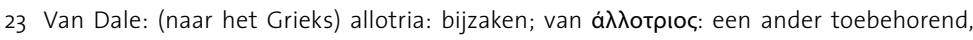
vreemd, niet eigen.

24 J. Domela Nieuwenhuis, De stand der gevangenisvraag, Tijdschrift voor Strafrecht, Deel II, 1888, bl. 266-267. 
komen. Ik beperk me hier tot de rol van strafrechter als oplegger van vrijheidsbenemende straffen: van de (vrijwel nooit opgelegde) principale hechtenis en de gevangenisstraf. Ik ga slechts incidenteel in op de voorlopige hechtenis, de plaatsing in een inrichting voor stelselmatige daders en de terbeschikkingstelling met bevel verpleging.

Straftoemeting, dames en heren is, voorzover $U$ dat al niet dacht, een vrij primitieve aangelegenheid. Ik durf dat wel te zeggen omdat ik al geruime tijd als raadsheer-plaatsvervanger medeverantwoordelijk ben voor het opleggen van vele detentiejaren en ander strafsancties. Als tijdens het raadkameren (dat hoofdzakelijk gaat over de vraag of de bewezenverklaring is dichtgetimmerd en er op alle gevoerde verweren voldoende is gerespondeerd, kortom of de uitspraak cassatieproof lijkt) eindelijk de vraag aan de orde is welke straf of maatregel moet worden opgelegd dan wordt het even stil en mag iedereen roepen welke sanctie hij redelijk vindt. Bij verschil van mening vindt er enige koehandel plaats, wordt er soms een blik geworpen op een oriëntatiepunt en wordt vervolgens een beslissing genomen. In chargeer enigszins maar niet heel erg veel. Alle juridische ratio lijkt opgebruikt bij het beantwoorden van de vier voorvragen van artikel 348 Sv en de eerste drie hoofdvragen van artikel 350 Sv. Bij de beantwoording van de vierde hoofdvraag: 'Wat geven we de veroordeelde?' wordt overgeschakeld van ratio op gewoonte en gevoel. In de appèlfase is het overigens wat makkelijker want dan wordt niet alleen gekeken naar wat de advocaat-generaal als eis heeft geformuleerd, maar vooral ook naar wat de rechter in eerste aanleg heeft gedaan. Een ongeschreven fatsoensregel brengt met zich mee, dat als het even kan de in eerste aanleg oplegde sanctie wordt gerespecteerd, tenzij er in appèl meer of minder bewezen is verklaard of als de persoonlijke omstandigheden van de dader intussen aanzienlijk zijn veranderd. In eerste aanleg heeft de rechtbank zulke richtpunten niet.

Natuurlijk zijn er in de meeste gevallen strafvorderingsrichtlijnen van de procureurs-generaal en oriëntatiepunten van het Landelijk Overleg van Voorzitters van Stafsectoren (LOVS) beschikbaar, en die worden er in raadkamer soms ook wel op nageslagen, maar even goed kan het overleg over de meest geschikt geachte sanctie beperkt zijn tot een vraag van de voorzitter aan de griffier: 'Wat geven we ook weer in dit soort gevallen?'. De belangrijkste vraagpunten zijn: moet de veroordeelde 'zitten' of niet? En zo ja: hoe lang dan wel? Het antwoord op de vraag 'zitten of niet' is wat 
makkelijker te geven als de verdachte in voorlopige hechtenis bevindt; hij is dan toch al gedetineerd. Als de verdachte blijkens diens justitiële documentatie al eerder een vrijheidstraf heeft ondergaan wordt het opleggen van een vrijheidsstraf meestal ook niet zo problematisch geacht. Als een eerdere detentie kennelijk niet heeft geholpen, vindt de rechter het vaak verstandig het dan nóg maar eens en dan voor een wat langere tijd te proberen. Toemeting van vrijheidsstraf, en ik ben zeker niet de eerste die dat beweert, is in hoge mate op intuïtie en gewoonte gebaseerd en maar zeer ten dele op rationele argumenten.

Verschillen in straftoemeting tussen rechtbanken en gerechtshoven in vergelijkbare zaken zijn herhaaldelijk vastgesteld en binnen dezelfde rechtbank en hetzelfde hof kunnen strafkamers aanzienlijk uiteenlopen in hun opvattingen over wat in een bepaald geval de juiste sanctie is. Uit het oogpunt van rechtsgelijkheid is dat, ook volgens de zittende magistratuur, onaanvaardbaar en gelijkheid of wel consistentie in straftoemeting is dan ook de noemer waaronder de discussie daarover wordt gevoerd. Naar mijn mening is gelijkheid zeker een belangrijk thema, maar de discussie over legitieme strafdoelen en over de motivering van met name de vrijheidsstraf is niet van minder belang, zeker in relatie tot de manier waarop sancties ten uitvoer dienen te worden gelegd.

Het lastige in elk debat over strafmotivering is dat het Wetboek van Strafrecht nergens aangeeft op welke gronden de rechter überhaupt straf mag opleggen en ook niet aangeeft welke doeleinden daarmee mogen worden nagestreefd. Zoals Duker in zijn proefschrift heeft gezegd heeft de rechter geen concreet referentiepunt in de wet waarmee hij de relevante omstandigheden in een strafzaak kan omzetten in een bepaalde straf. ${ }^{25}$ De Hoge Raad draagt in deze ook niet bij tot helderheid omdat dit rechtscollege de strafrechter de vrije hand laat bij het formuleren van strafdoelen en in de keuze van factoren die het soort, de maat en de modaliteit van de sanctie bepalen. ${ }^{26}$ Dit leidt tot - wat De Keijser

25 Marius Duker, Legitieme straftoemeting - Een onderzoek naar de legitimiteit van de straftoemeting in het licht van het gelijkheidsbeginsel, het democratiebeginsel en het beginsel van een eerlijke procesvoering, Den Haag 2003, bl. 73.

26 Bijv.: HR 15 juli 1985, NJ 1986, 184 en HR 25 november 2003, Nieuwsbrief Strafrecht 22 januari 2004, afl. 1, nr. 18.

27 Jan W. de Keijser, Punishment and Purpose - From Moral Theory to Punishment in Action, Amsterdam 2000, bl. 25-28. 
noemt - hybride strafmotiveringen, waarin met elkaar conflicterende elementen van vergelding en doelmatigheid om de voorrang strijden. Dergelijke, innerlijk tegenstrijdige, strafmotiveringen zijn volgens de heersende opvattingen gegrond op de zogenaamde verenigingstheorie. Mijns inziens zijn zij het product van - en ik citeer hier weer De Keijser ${ }^{27}$ - eclectisme, welk 'isme' kan worden omschreven 'een samenraapsel van nogal heterogene denkbeelden zonder deze tot een nieuwe, hechte eenheid te verbinden.' ${ }^{28}$ Franken, een gezaghebbende strafpleiter, zegt in dit verband dat raadslieden nauwelijks inzicht hebben in de wijze waarop de weging van relevante factoren uitmondt in de rechterlijke straftoemetingsbeslissing en meent dat 'welhaast per definitie' een element van toeval of van willekeur in de straftoemetingsbeslissing besloten ligt. ${ }^{29}$

Ik haast me te zeggen dat, zeker in de wat zwaardere zaken, de strafrechter zijn best doet om in zijn uitspraak uit te leggen welke in en buiten de persoon van de dader gelegen factoren de sanctie hebben bepaald. Dat neemt niet weg dat diezelfde rechter nog steeds zoekende is naar algemeen toepasbare criteria die de straftoemeting op zijn minst minder willekeurig kunnen doen lijken. Met name in de sinds 2000 verschijnende speciale Straftoemetingsbulletins bij het tijdschrift voor de rechterlijke macht Trema is door rechters en wetenschapsbeoefenaars geschreven over het strafmotiveringsprobleem. In het kader daarvan heeft Otte opgemerkt dat het debat over de straftoemeting vooral lijkt gefocust op de doorwerking van het gelijkheidsbeginsel. Volgens hem wordt het overleg dat daarover tussen de strafsectoren wordt gevoerd, meer bepaald door (ik citeer hem) 'rekenkundig plussen en minnen', dan door een inhoudelijk debat. Volgens Otte kan zelfs de meest consciëntieuze strafmotivering met name de strafduur niet op een redengevende wijze verklaren omdat naar zijn ervaring de vraag wat relevant is in de meeste straftoemetingsmodellen al of niet impliciet vanuit een vergeldingsdoel wordt beantwoord. De ernst van het gepleegde delict bepaalt volgens Otte de strafmaat. ${ }^{30}$

28 Grote Winkler Prins, deel 6, COUL-EGY, MCMLXVIII, Amsterdam - Brussel, bl. 739.

29 A.A. Franken, Een blijvend probleem: over straftoemeting en consistentie, Trema Straftoemetingsbulletin 2, november 2005, bl. 56-58

30 M. Otte, Het probleem van straffen, Trema - Straftoemetingsbulletin 1, april 2000, bl. 
$\mathrm{Er}$ is door de strafrechters hard gewerkt aan instrumenten om in ieder geval al te grote, niet verklaarbare, verschillen in straftoemeting tegen te gaan. Een van die instrumenten was de in 2002 operationeel geworden, aanvankelijk alleen door rechters en later ook door advocaten te raadplegen, databank consistente straftoemeting, waar sinds 2000 alle uitspraken van gerechtshoven waarbij straffen van vier jaar of meer worden opgelegd in worden opgenomen. Het projectteam dat die databank heeft opgezet had overigens bescheiden verwachtingen van de resultaten daarvan. Het zei zich ervan bewust te zijn dat de straftoemeting wellicht uiteindelijk een intuïtieve aangelegenheid is, omdat bij de straftoemeting te veel factoren een rol spelen om in een model te vangen. ${ }^{31}$ Deze bescheiden verwachtingen van de projectgroep werden bewaarheid toen uit onderzoek bleek dat deze databank niet werkte. ${ }^{32}$

De databank consistente straftoemeting is - zoals bekend - niet het enige instrument waarmee een zekere gelijkheid in straftoemeting kan worden nagestreefd: ook de strafvorderingsrichtlijnen van het openbaar ministerie en de door het Landelijk Overleg van Sectorvoorzitters (LOVS) vastgestelde oriëntatiepunten straftoemeting spelen daarbij een rol. De functie van dit soort landelijke ijkpunten wordt echter weer ondergraven door het bestaan van - niet openbare-lokale lijstjes met oriëntatiepunten van rechtbanken, waarvan het bestaan is gesignaleerd door Fokkens en Duker in een artikel met als titel Straftoemeting als rechtsvinding, waarin zij pleiten voor de ontwikkeling van een straftoemetingsrecht, gebaseerd op bindende regels. 33 Ik vind dat een belangrijk voorstel en kom daar zodadelijk op terug.

Het voorlopige eindpunt in het streven naar een meer inzichtelijke strafmotivering is het Project Motiveringsverbetering in Strafvonnissen (PROMIS), waarvan intussen een tweede versie is geëvalueerd. Het projectplan Promis II propageert - aldus het Eindrapport Promis II - het

31 R.C.P. Haentjens, Over het motiveren van straffen - De cruciale rol van de strafmotivering volgens de ontwerpers van de databank voor consistente straftoemeting, Trema Straftoemetingsbulletin 3, november 2002, bl. 65-71.

32 Daarover: A. Schmidt, De cirkel is rond: over instrumenten die helpen bij straftoemeting, Trema Straftoemetingsbulletin 2, november 2005, bl. 43-47 en R.C.P. Haentjens, Straftoemeting als beredeneerde keuze of het nut van de databank consistente straftoemeting, Straftoemetingsbulletin 2, november 2005, bl. 48-54.

33 J.W. Fokkens en M.J.A Duker, Straftoemeting als rechtsvinding, Trema Straftoemetingsbulletin 1, juni 2006, bl. 1-5. 
hanteren van een vast model voor de straf- en maatregelmotivering in uitspraken. Daarin dient te worden opgenomen: a. een korte leesbare beschrijving van de feiten; b. de feiten die de officier bewezen acht en de straf die daarvoor wordt geëist; c. het standpunt van de verdediging; d. eventuele (deel)vrijspraken in eerste aanleg; e. (facultatief) de straf die in soortgelijke zaken wordt opgelegd; f. de wettelijke strafen maatregelmotivering; $g$. nadere straf- en maatregelmotivering voortvloeiend uit uitdrukkelijk door de verdediging of het Openbaar Ministerie onderbouwde standpunten, het debat ter terechtzitting of de jurisprudentiële motiveringseisen; h. feitgerelateerde factoren, de impact van het feit met een opsomming van algemene en specifiek objectieve factoren die van invloed zijn op de sanctietoemeting; en i. verdachte gerelateerde factoren met een opsomming van subjectieve factoren die van invloed zijn op de sanctietoemeting.

De resultaten van Promis II zijn door een toetsingscommissie onder voorzitterschap van Fokkens onderzocht. De commissie was ervan overtuigd geraakt 'dat het weergeven van oriëntatiepunten/ bandbreedtes als uitgangspunt waartegen het concrete geval wordt afgezet de strafmotivering inzichtelijker en begrijpelijker maakt.' Hoe en door wie een rechtelijk straftoemetingsbeleid zou moeten worden vormgegeven en hoe het zich verhoudt tot de door het openbaar ministerie gehanteerde strafvorderingsrichtlijnen viel buiten het bestek van het door de commissie opgestelde evaluatierapport. De commissie gaf wel als haar mening dat het opnemen van uitgangspunten bij de straftoemeting de uitleg aan de burger omtrent de opgelegde straf bevordert.34 Het is volgens Ficq en Sterk, leden van de leden van de Promis-kamer bij het gerechtshof te den Bosch, moeilijk om alle rechters aan het 'promissen' te krijgen. Daar zal volgens hen een cultuuromslag voor nodig zijn. 35

Het ontbreken van wettelijke uitgangspunten blijft naar mijn mening de zwakke stee in de strafmotivering. Het duidelijkst vond ik dit verwoord in een bijdrage van Kortenhorst - zelf rechter - aan het straftoemetingsdebat, waar hij zei, dat het begrip gelijkheid in deze

34 Eindrapport Promis II - Project motiveringsverbetering in strafvonnissen, [zonder auteur] 's-Hertogenbosch 2007, bl. 34-35.

35 C.H.W.M Sterk en C.R.L.R.M. Ficq, Promis: inzicht in de gedachtegang van de rechter, Nederlands Juristenblad 18 januari 2008, nr. 3, bl. 157. 
discussie een veel te groot, zelfs storend accent heeft gekregen'. Hij wees er op - en dat is volgens mij des Pudels Kern - dat 'iedere verwijzing naar wat straffen is en met welk doel wij dit doen in de discussie schittert door afwezigheid'. Naar zijn - alweer door mij gedeelde mening - is straftoemeting een bijna onmogelijke opdracht nu er geen duidelijke opvattingen aan het strafrechtelijke stelsel ten grondslag liggen. Of je nu uitgaat van straftoemetingsrichtlijnen of oriëntatiepunten: in beide gevallen blijft de vraag waarop het beginpunt is gebaseerd. Ik citeer Kortenhorst weer; 'Waarom geldt voor een autodiefstal 5 weken als basisstraf, waarop naar boven of naar onder mag worden gevarieerd? Waarom niet twaalf weken of drie dagen?' Voor Kortenhorst is het wel duidelijk: hij denkt dat het komt omdat nog steeds een wezenlijke factor buiten beeld blijft: de strafdoeleinden.' Een rationele constructie is naar zijn mening alleen mogelijk als de beslisser eerst zijn premissen helder formuleert en daaruit zijn beslissing afleidt. Voor de straftoemeting betekent dit dat de rechter in iedere zaak opnieuw moet verwoorden wat hij in dit specifieke geval ziet als het doel van de straf. ${ }^{36}$

Veel klassieke juristen zullen de gedachte blijven koesteren dat straftoemeting altijd op een aantal onweegbare factoren - de fameuze imponderabilia - zal blijven berusten, dat straftoemeting niet zozeer een techniek is, als wel een kunst. Het zijn ook zij, die belang blijven hechten aan een element van vergelding als grond dan wel doel van elke bestraffing al of niet in combinatie met andere bedoelingen. Het zijn zij die de kunst denken te verstaan om de ernst van het bewezen verklaarde feit te kunnen inschatten en middels een voor derden niet te volgen denkproces te kunnen omzetten in een concreet aantal dagen, maanden, jaren detentie.

Ik meen dat een rationele, doelgerichte straftoemetingsbeslissing een voorwaarde is om aan dader, benadeelde en derden - en ja ook aan de belastingbetaler - uit te kunnen leggen waarom een bepaalde strafrechtelijke interventie noodzakelijk is, en meer in het bijzonder om uit te kunnen leggen waarom in bepaalde gevallen niet kan worden volstaan met een extramurale sanctie. Ik vind dan ook dat over het zo-even genoemde voorstel van Fokkens en Dukers om de straftoemeting

36 B.M. Kortenhorst, De vraag is en blijft: hoe te voorkomen dat we veranderen in een grijze gehaktbal. - Want wat is motiveren en krijgen we daar nog genoeg tijd voor?, Trema -Straftoemetingsbulletin 3, november 2002, bl. 72-78. 
en strafmotivering aan regels - en ik bedoel dan wettelijke regels - te binden serieus dient te worden overdacht. Inspiratie daarvoor kan bij onze oosterburen worden gevonden. De Nijmeegse strafrechtgeleerde Tak heeft enige tijd geleden gewezen op het Duitse Wetboek van Strafrecht dat een aparte titel over straftoemeting kent. In artikel in artikel 46, tweede lid, van dat wetboek is een aantal criteria voor straftoemeting vastgelegd. 37 Dat is een rijtje 'Promis-achtige' factoren, die de Duitse strafrechter uitdrukkelijk in acht moet nemen bij het onderbouwen van zijn straftoemetingsbeslissing. ${ }^{38}$ Tak duidt erop dat de Duitse wetgever niet heeft aangegeven welk gewicht aan de desbetreffende factoren moet worden toegekend en dat maakt het lastig om hun invloed op de straftoemetingsbeslissing objectief vast te stellen. In het eerste lid van genoemd wetsartikel wordt de verwijtbaarheid van het feit aan de dader, de schuld, als enige grond voor bestraffing genoemd. Dat zelfde artikellid zegt dat de rechter bij de straftoemeting rekening ook moet houden met de invloed van de straf op het verdere leven van de dader.

Het lijkt mij voor de ontwikkeling van een werkelijk straftoemetingsrecht een noodzakelijke voorwaarde dat ook in het Nederlandse Wetboek van Strafrecht een aparte titel wordt opgenomen over de straftoemeting. Daarin zouden dan wat mij betreft niet alleen factoren moeten worden

37 P.J.P. Tak, Straffen en bestraffen in Duitsland, Trema - Straftoemetingsbulletin 1, februari 2001, bl. 3-8.

\section{$38 \$ 46$ StGB - Grundsätze der Strafzumessung}

(1) Die Schuld des Täters ist Grundlage für die Zumessung der Strafe. Die Wirkungen, die von der Strafe für das künftige Leben des Täters in der Gesellschaft zu erwarten sind, sind zu berücksichtigen.

(2) Bei der Zumessung wägt das Gericht die Umstände, die für und gegen den Täter sprechen, gegeneinander ab. Dabei kommen namentlich in Betracht:

die Beweggründe und die Ziele des Täters,

die Gesinnung, die aus der Tat spricht, und der bei der Tat aufgewendete Wille,

das Maß der Pflichtwidrigkeit,

die Art der Ausführung und die verschuldeten Auswirkungen der Tat, das Vorleben des Täters, seine persönlichen und wirtschaftlichen Verhältnisse sowie sein Verhalten nach der Tat, besonders sein Bemühen, den Schaden wiedergutzumachen, sowie das Bemühen des Täters, einen Ausgleich mit dem Verletzten zu erreichen.

(3) Umstände, die schon Merkmale des gesetzlichen Tatbestandes sind, dürfen nicht berücksichtigt werden. 
opgesomd die de rechter in overweging dient te nemen bij het opleggen van een straf of maatregel. Ook dient daarin (of in de bijbehorende memorie van toelichting) te worden aangegeven wat het relatieve gewicht van die factoren is. Daarnaast dient in zo'n nieuwe titel over straftoemeting worden vastgelegd welke doeleinden met een strafrechtelijke sanctionering mogen worden nagestreefd. De wetgever mag er geen misverstand laten bestaan wat legitieme strafdoelen zijn. Een bijzondere motiveringsplicht voor de rechter zou in die titel moeten worden opgenomen waar het gaat om de oplegging van intramurale strafsancties. Die zouden slechts dan mogen worden opgelegd wanneer uit een recente, wetenschappelijk geteste, risicoanalyse blijkt dat de betrokkene dermate gevaarlijk is voor zichzelf, voor anderen, of voor de algemene veiligheid van personen of goederen39, dat niet met een extramurale interventie kan worden volstaan. Dat zou wat mij betreft nog niet voldoende zijn. De rechter zal, indien hij oplegging van een intramurale sanctie op genoemde gronden geboden acht, vervolgens ook verplicht moeten worden om in zijn uitspraak aan te geven wat de inhoud van de intramurale interventie dient te zijn, dat wil zeggen, welke problematiek door en in de penitentiaire inrichting moet worden aangepakt.

De rechter die oplegging van een intramurale sanctie overweegt zal zich over de meeste adequate tenuitvoerlegging daarvan door een of meer gedragskundigen moeten laten adviseren. Dat laatste is thans nog problematisch omdat er nog niet zo veel effectieve, intramuraal toepasbare, gedragsinterventies beschikbaar zijn. De Erkenningscommissie gedragsinterventies justitie, die gedragsinterventies op hun effectiviteit beoordeelt, heeft tot nu toe slechts twee gedragsinterventies volledig erkend en twee voorlopig. In december 2007 is de Training voor cognitieve vaardigheden erkend. Dat is een training van drie maanden in het kader waarvan delictplegers leren - kort gezegd - om eerst te denken en dan pas te handelen. De tweede, in juni 2008 erkende gedragsinterventie heeft de naam Arbeidsvaardigheden en is bedoeld om volwassen justitiabelen inzicht te geven en vaardigheden te leren waarmee ze (beter) in staat zijn werk te krijgen en te houden. Hoewel deze interventies niet speciaal zijn ontworpen voor intramurale toepassing valt niet in te zien waarom zij daartoe niet geschikt zouden kunnen worden gemaakt. De twee voorlopig erkende programma's zijn een agressieregulatietherapie (genaamd ART Wiltshire Nederland),

39 Vgl. artikel 37 lid 1 Sr. 
wél ontworpen voor intramurale toepassing en de Leefstij/training voor verslaafde justitiabelen.

Zolang er geen op de problematiek van de dader toegespitste (al dan niet voorlopig) erkende gedragsinterventies voorhanden zijn die intramuraal kunnen worden toegepast, dient de rechter in zijn uitspraak mijns inziens tenminste aan te geven aan welke problemen in een voor de veroordeelde op te stellen detentieplan in het bijzonder aandacht moet worden gegeven. Het strafvonnis kan zo een kader en ijkpunt voor de bejegening van veroordeelden worden. Op de inhoud van een dergelijk detentieplan zal ik zodadelijk ingaan wanneer ik zal aangeven welke wijzigingen in de Penitentiaire beginselenwet zouden moeten worden aangebracht om de inhoud van de tenuitvoerlegging juridisch in te kaderen. Eerst wil ik nog iets zeggen over motivering van de duur van de gevangenisstraf, die in mijn visie materieel het karakter zou krijgen van een maatregel, van een op de problematiek van de veroordeelde toegespitste gedragsinterventie.

In hun door mij al eerder genoemde brief aan de tweede Kamer van 29 augustus 2008 over maatregelen tegen recidive hebben de Minister van Justitie en zijn staatssecretaris erop gewezen dat $25 \%$ van de gedetineerden niet langer van twee weken in een penitentiaire inrichting verblijft, dat bijna 50\% er korter dan een maand verblijft en ruim 60\% korter dan twee maanden. Een onlangs door het ministerie van Justitie voor NRC-Handelsblad vervaardigd overzicht van de gemiddelde detentieduur wijst uit dat in 2007 bijna driekwart van alle plm. 40.000 gedetineerden die jaarlijks de penitentiaire inrichtingen binnen komen daar korter dan 6 maanden verblijft. ${ }^{\circ}$ Het moge duidelijk zijn, dat deze termijnen veelal te kort zijn om een behoorlijke, persoonsgerichte bejegening op gang te brengen. Het gevangeniswezen zal kort-verblijvers niet veel anders kunnen bieden dan 'bad, bed en brood.' Het is dan ook te prijzen dat de bewindslieden de toepassing van korte en in feite zinloze detentie wil voorkomen door in het kader van voorwaardelijke veroordelingen te werken aan gedragsverandering en daarmee te besparen op kostbare detentiedagen (een gedetineerde kost gemiddeld zo'n $200 €$ per dag). Het zou goed zijn als de minister dit plan zou borgen door het opleggen van korte straffen wettelijk moeilijker te maken. Dat zou hij kunnen doen door in het Wetboek van Strafrecht een bepaling op te laten nemen, vergelijkbaar met artikel 47 , eerste lid van het Duitse Wetboek van Strafrecht, dat zegt dat een vrijheidsstraf van minder dan 
zes maanden alleen in uitzonderingsgevallen opgelegd dient te worden. ${ }^{41}$ Daarnaast zou de minister eens kunnen nadenken over afschaffing van de vervangende hechtenis, die het aantal kort-verblijvenden in de penitentiaire inrichtingen danig zou kunnen doen verminderen zodat alle beschikbare menskracht kan worden gebruikt voor de inhoudelijke bejegening van de meest problematische gedetineerden.

\section{Aanpassing van de Penitentiaire beginselenwet}

Wil men door een rationele, probleemgeoriënteerde straftoemeting de kwaliteit van de detentie verbeteren en op die manier de recidivegraad terugbrengen tot aanvaardbare proporties, dan dient de Penitentiaire beginselenwet zo te worden ingericht dat die het kader biedt waarbinnen de bedoelingen van de strafrechter kunnen worden gerealiseerd. Het karakter van deze wet zal dan moeten veranderen van een set minimumregels voor de bejegening van gedetineerden in een regeling die primair de tenuitvoerlegging van effectieve gedragsinterventies faciliteert. Dat dient in de eerste plaats tot uitdrukking te komen in de thans in artikel 2 geformuleerde algemene doelstelling van de Penitentiaire beginselenwet en te worden uitgewerkt in een daaraan toe te voegen hoofdstuk over detentieplanning, dat thans aan deze wet ontbreekt. Er is in de praktijk wel sprake van een zekere detentieplanning, maar de taak en functie van de thans daarmee belaste Bureaus Selectie en Detentiebegeleiding en van de medewerkers maatschappelijke dienstverlening (MMD-ers) is niet in de Penitentiaire beginselenwet of in een van de daarbij behorende regelingen vastgelegd.

Over het doel van de tenuitvoerlegging van de straffen of maatregelen zegt artikel 2, eerste lid, van de huidige Penitentiaire beginselenwet thans het volgende:

'Met handhaving van het karakter van de vrijheidsstraf of de vrijheidsbenemende maatregel wordt de tenuitvoerlegging hiervan zoveel mogelijk dienstbaar gemaakt aan de voorbereiding van de terugkeer van de betrokkene in de maatschappij.'

$41 \S 47$ Kurze Freiheitsstrafe nur in Ausnahmefällen (1) Eine Freiheitsstrafe unter sechs Monaten verhängt das Gericht nur, wenn besondere Umstände, die in der Tat oder der Persönlichkeit des Täters liegen, die Verhängung einer Freiheitsstrafe zur Einwirkung auf den Täter oder zur Verteidigung der Rechtsordnung unerlässlich machen. 
Het eerste deel van dit artikellid is allerminst duidelijk, want welke betekenis moet worden toegekend aan de zinsnede 'met handhaving van het karakter van de straf'? Een betere formulering zou wat mij betreft de volgende zijn: De tenuitvoerlegging van de vrijheidsstraf of de vrijheidsbenemende maatregel is in overeenstemming met doel en strekking van de beslissing waarbij deze werd opgelegd. Daarmee zou dan in de Penitentiaire beginselenwet worden vastgelegd dat de inhoud van de bejegening van gevangenen primair wordt bepaald door de strafrechter. In het tweede deel van art. 2, eerste lid van de Penitentiaire beginselenwet zou wat mij betreft de term 'zoveel mogelijk' dienen te worden vervangen door de woorden 'is gericht op' omdat reclassering, dat wil zeggen, reïntegratie in de vrije samenleving, blijkens artikel 10, derde lid, eerste volzin van het Internationaal Verdrag inzake Burgerrechten en Politieke Rechten een fundamenteel recht van elke gedetineerde is en dus een kerntaak van elk gevangenisstel en geen bijkomstig doel behoort te zijn.

Naast een herformulering van de algemene doelstelling van de Pbw is in mijn optiek aanvulling van deze wet met een hoofdstuk onder de titel Detentieplanning noodzakelijk. We kunnen daarbij te rade gaan bij de Beginselenwet Justitiële Jeugdinrichtingen en het daarbij behorende Reglement Justitiële Jeugdinrichtingen. Artikel 20 van de Beginselenwet Justitiële Jeugdinrichtingen geeft de directeur van een opvanginrichting de bevoegdheid om voor elke jongere die zijn inrichting binnen komt als voorlopige gehechte of als veroordeelde - een verblijfsplan vast te stellen; hij is verplicht dat te doen voor jongeren die na veroordeling een stafrestant van drie maanden of meer hebben. In hoofdstuk 5 van het genoemde Reglement wordt uitgewerkt wie er allemaal bij de vaststelling van een verblijfsplan zijn betrokken, welke elementen zo'n plan in ieder geval moet bevatten en hoe het plan periodiek moet worden geëvalueerd. Het verblijfsplan vormt de kern en het richtsnoer van de bejegening van jongeren die in opvanginrichtingen zijn opgesloten Het kan zonder veel moeite worden getransponeerd naar een nieuw hoofdstuk in de Penitentiaire beginselenwet en zou dan detentieplan kunnen worden genoemd, geheel in lijn met de terminologie die door de minister van Justitie en diens staatssecretaris is gebruikt in de brief aan de Tweede Kamer, die ik zopas noemde.

Als het gaat om personen die zich in voorlopige hechtenis bevinden en nog niet zijn veroordeeld kan een detentieplan vanzelfsprekend nog 
niet worden afgestemd op de inhoud van een vonnis. Voor hen kan dan een voorlopig detentieplan worden opgesteld, dat na veroordeling in eerste aanleg kan worden afgestemd op de inhoud van het vonnis.

Zonder hier in details te willen treden dient elk detentieplan naar mijn mening tenminste de volgende elementen te bevatten:

- een inhoudelijke omschrijving van het strafbare gedrag dat aanleiding tot de detentie was;

- het door de rechter in zijn uitspraak vermelde doel van de opgelegde sanctie

- beschrijving van de inhoud van de bejegening in het licht van de opgelegde sanctie

- medische gegevens voorzover relevant voor de bejegening

- aanduiding van de detentiefasering

In het aan de Penitentiaire beginselenwet toe te voegen hoofdstuk over detentieplanning, dan wel in de Penitentiaire maatregel zouden de taak en bevoegdheden van de met die planning belaste diensten nauwkeurig moeten worden omschreven, zodat gedetineerden precies weten waartoe zij verplicht zijn en wat zij van die diensten aan inspanningen mogen verwachten.

Net als het geval is bij jeugdige gedetineerden zou een detentieplan voor volwassenen periodiek, dat wil zeggen elke 6 maanden, geëvalueerd dienen te worden. De evaluaties zou vervolgens ter kennis van de strafrechter dienen te worden gebracht. Deze zou de mogelijkheid moeten krijgen om op basis daarvan te adviseren over voortzetting of wijziging van het detentieplan over deelname aan en inhoud van een penitentiair programma en over eventueel aan een voorwaardelijke invrijheidstelling te stellen bijzondere voorwaarden. In die beperkte zin zou de rechter dan betrokken kunnen worden bij de strafuitvoering, zonder hem tot strafuitvoeringsrechter te 'bombarderen'. De voordelen van een dergelijke betrokkenheid lijken me evident: de tenuitvoerlegging van de straffen wordt afgestemd op wat de rechter ermee bedoeld heeft en hij kan zelf beoordelen of wat hij met de straf wilde in de praktijk kan worden gerealiseerd. De rechter kan daarvan leren en zijn straftoemetingsbeslissingen daardoor telkens beter motiveren.

De vraag die sommigen zullen stellen of de strafrechter zich überhaupt wel met de tenuitvoerlegging van zijn eigen beslissing mag bemoeien. 
Met de rechtstheoreticus Ippel meen ik dat dat wel degelijk zou kunnen, dat er meer dan genoeg redenen zijn om, zoals Ippel zegt 'de traditionele terughoudendheid bij de rechterlijke macht ten aanzien van de executie van strafrechtelijke sancties kritisch tegen het licht te houden.' 42

\section{Ik vat samen}

Een groot deel van de gedetineerden keert na hun invrijheidstelling weer snel in de gevangenis terug. De straf draagt kennelijk weinig bij tot het voorkomen van recidive. De kostbare straftijd wordt nauwelijks benut om daders tot een andere, delictvrije, levensstijl te stimuleren. Het voorkomen van 'detentieschade' lijkt het hoogst haalbare doel. Slechts een klein aantal gedetineerden komt enkele maanden voor het ontslag in aanmerking voor het kort geleden geïntroduceerde reïntegratieprogramma 'Terugdringen Recidive' waarvan de resultaten pas over enkele jaren bekend zullen zijn. De gevangenisstraf is thans geen effectieve gedragsinterventie maar verloren tijd. Het gevangeniswezen zelf doet - getuige de vele beleidsnota's die sinds de Tweede Wereldoorlog zijn verschenen - wel regelmatig pogingen om zichzelf te verbeteren, maar dat heeft tot nu toe weinig opgeleverd, vooral omdat die hervormingspogingen niet worden gerelateerd aan de straftoemeting. Dat kan veranderen als de strafrechter richting gaat geven aan de tenuitvoerlegging van de gevangenisstraf, door in zijn vonnissen zo nauwkeurig mogelijk aan te geven op welke grond en met welk doel deze straf wordt opgelegd. Het vonnis kan zo de basis worden voor een rationele detentieplanning en kan zo de kwaliteit van de detentie aanzienlijk verhogen. De strafrechter dient zich er regelmatig van te vergewissen dat de straf die hij heeft opgelegd ook zo wordt uitgevoerd als hij bedoeld had. Daartoe dient hij actief betrokken te worden bij een periodieke evaluatie van de manier waarop detentieplannen worden uitgevoerd en dient hij een adviserende rol te krijgen bij beslissingen over detentiefasering en voorwaardelijke invrijheidstelling.

Wat ik heb willen aangeven is dat de gescheiden werelden van straftoemeting en tenuitvoerlegging elk a part niet optimaal functioneren en dat afstemming van de tenuitvoerlegging op goed gemotiveerde, instructieve uitspraken de voorwaarden kunnen scheppen voor een optimale bejegening van gedetineerden. Als realist verbeeld ik me niet

42 P.C. Ippel, De geketende strafrechter?, Justitiële Verkenningen, 2007, nr. 6, bl. 61. 
dat het in werkelijk ook snel de kant op zal gaan die ik voor juist houd, maar ik wil op deze manier wel een bijdrage leveren tot het debat over de kwaliteit van de detentie en over de verdere ontwikkeling van het detentierecht in het bredere kader van een straftoemetingsrecht.

\section{Tenslotte dank}

Hier aan het eind van mijn verhaal gekomen past het mij een aantal personen dank te betuigen. In de eerste plaats dank ik Louk Hulsman, G.A.P. Hoefnagels en Hencvan Maarseveen voor de lessen in onafhankelijk om niet zeggen 'dwars' denken die zij mij tijdens mijn studie aan de Juridische faculteit van de Nederlandse Economische Hogeschool te Rotterdam hebben gegeven. Constantijn Kelk was en is nog steeds mijn voorbeeld waar het gaat om het streven naar de rechtsbescherming en emancipatie van gedetineerden.

Tenslotte dank ik het College van Bestuur van de Universiteit Maastricht voor mijn benoeming die ik beschouw als een bekroning van mijn werk op het gebied van het detentierecht. Ik beloof $U$ dat ik de tijd die mij nog rest zal gebruiken om het detentierecht verder te ontwikkelen.

Dixi - ik heb gezegd. 
